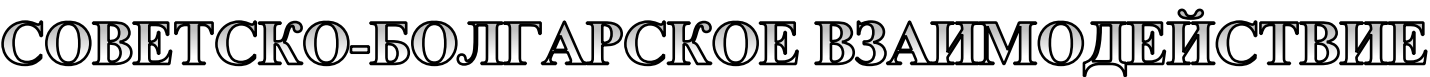

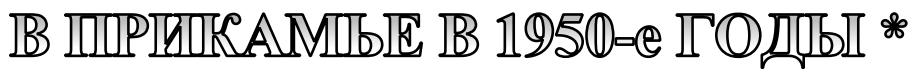

М.С. Каменских, Пермский федеральный исследовательский иентр УрО РАН

На основании не публиковавшихся ранее архивных материалов фонда АООТ «АЗОТ» Государственного архива Пермского края реконструируются основные события, связанные с обучением болгарских специалистов на Березниковском азотно-туковом заводе в 1950-е годы. Имеющиеся источники позволяют реконструировать обстоятельства их приезда, ход и содержание учебного процесса. После обучения в Прикамье болгарские специалисты возвращались на родину, обеспечивая кадровый состав развивающейся химической промышленности. В частности, прошедшие в Березниках обучение специалисты были отправлены на Димитровградский химический комбинат, один из фллагманов всей промышленности Болгарии 1950-х годов. Проведенное исследование позволяет сделать вывод, что Прикамье внесло существенный вклад в промышленное развитие Болгарии 1950-х годов.

Ключевые слова: Болгары, Димитровград, Березники, СССР .

Во второй половине XX века советско-болгарское взаимодействие вышло на новую ступень развития. Провозглашенная в 1946 году Народная Республика Болгария (НРБ) вошла в блок стран «народной демократии» и приступила к созданию социалистической модели народного хозяйства при поддержке СССР. Уже в марте 1945 года СССР и Болгария подписали первое торговое соглашение, в рамках которого Болгария получила безвозмездную помощь на восстановление промышленности, а с 1947 года в Болгарию на регулярной основе начали поступать промышленное оборудование и материалы для строительства крупных промышленных объектов [7, с. 439].

После подписания в 1948 году Договора о дружбе, сотрудничестве и взаимной помощи между СССР и НРБ [5, с. 4] и ряда последующих соглашений между странами была создана целая система взаимодействия в самых различных отраслях. В эти годы СССР оказал огромную финансовую и техническую помощь Болгарии в развитии промышленности, экономики и сельского хозяйства [7, с. 458-489]. Практически все крупные предприятия, построенные в Болгарии после 1950 года, строились при участии советских специалистов. В то же время граждане НРБ приезжали в СССР для обучения и повышения квалификации.

Особую роль в подготовке специалистов промышленной сферы играл Урал. Известно, что в 1950 годы болгары проходили обучение и практику на многих предприятиях этого региона, в том числе Молотовской области [12]. В этот период данный регион активно развивался [9]. Несмотря на в целом сложные, связанные с убылью населения демографические процессы в стране, число жителей Пермской области в период с 1939 по 1959 год

* Исследование выполнено при поддержке РФФИ, грант №19-59-18003 «Болгары Урала и Сибири в XX-XXI веках: история, культура, идентичность». 
увеличилось в 1,5 раза - с 2 до 2,9 млн человек [2; 3]. Прирост населения обеспечивался за счет миграций, как внутренних, так и внешних. В эти годы участие в строительстве разных объектов Пермской области принимали выходцы из КНР, ГДР и других стран. Иностранцев приглашали как для обучения, так и для участия в строительстве капитальных объектов $[10$, c. 75-76]. Так, на предприятиях Молотовстроя в 1950-е годы проходило обучение и трудилось свыше 1000 китайцев $[8$, с. 20-28]. Своим присутствием иностранцы усложняли этнический и социокультурный облик региона.

Прикамье сыграло важную роль в становлении химической промышленности Болгарии, поскольку именно здесь проходили обучение специалисты данного профиля. Димитровградский химический комбинат, официально считавшийся «крупнейшей новостройкой первой болгарской пятилетки» [4, с. 267], строился при участии советских специалистов: они подготовили проектную документацию, участвовали в руководстве строительством, монтаже и пуске комбината. С целью подготовки специалистов для работы на комбинате после его запуска в эксплуатацию Министерством химической промышленности (МХП) СССР был издан приказ № 49 от 18.01.1950«О правильной организации и лучшей подготовке специалистов и рабочих промышленности стран народной демократии, осуществляемой на предприятиях, в научно-исследовательских институтах проектных организациях Министерства химической промышленности». Согласно этому документу, практиканты из соседних государств, в том числе Болгарии, направлялись на предприятия в Березники, Кемерово, Сталиногорск и Лисичанск [3, с. 64]. По итогам обучения они должны были составить инженернотехнический персонал строящегося Димитровградского химического завода. В Прикамье практиканты проходили подготовку на базе Березниковского азотно-тукового завода (БАТЗ), производственные цеха которого, к слову сказать, в 1930-е годы проектировал инженер болгарского происхождения Иван Добрев [11].
Данная статья посвящена анализу источников, касающихся истории прохождения специалистами из Болгарии практики на БАТЗе. Основным источником исследования послужила делопроизводственная документация из фонда Р-1656 «АООТ «Азот» Государственного архива Пермского края (ГАПК). Данный исторический эпизод еще не нашел отражения в историографии, источники впервые вводятся в научный оборот.

Отправной точкой для привлечения практикантов из Болгарии в Прикамье может считаться «Договор на теоретическое обучение и производственную практику специалистов и рабочих Болгарского завода», подписанный в мае 1950 года между Управлением внешних сношений Министерства химической промышленности СССР и БАТЗом. По договору планировалось привлечь специалистов из Болгарии для «теоретического обучения и прохождения производственной практики» на заводе в период с марта по ноябрь 1951 года. БАТЗ брал на себя обязательства по теоретическому обучению группы болгар в течение 1951 года, включая материально-техническое и медицинское сопровождение, а Управление внешних сношений оплачивало их обучение [3, с. 79-80]. Главное управление азотной промышленности МХП в переписке с руководством БАТЗ обращало внимание на необходимость «тщательно подготовиться к приему болгарских специалистов и рабочих и принять все необходимые меры к их качественному теоретическому и производственному обучению» $[3$, с. 60].

В течение второй половины 1950 года подготовительная работа была проведена, и с мая 1951 года болгарские специалисты начали приезжать в Березники. Сохранились сведения о нескольких группах практикантов численностью от 10 до 20 человек. Все они приезжали на срок от 3 до 8 месяцев. Судя по источникам, среди них были как студенты (1929 г.р.), так и опытные инженеры. Самой младшей по спискам была Мария Филипова (21 год), самым старшим Петр Статев, имеющий высшее химическое образование (руководитель группы). 
На момент поездки ему было 36 лет. Уровень образования практикантов тоже различался. Среди них были и выпускники вузов, и люди совсем без образования, и взрослые учащиеся вечерних школ (3-5-го классов, таких было большинство [3, с. 103]. Все практиканты проходили обучение в Центральной заводской лаборатории и цехе слабой азотной кислоты и компрессии.

Источники позволяют практически полностью реконструировать процесс и программу обучения болгарских специалистов. Учебные планы руководство завода разрабатывало самостоятельно. Планы включали в себя теоретическую и практическую части. В рамках теоретического обучения практиканты должны были пройти предметы «Русский язык» (72 часа), «Техника безопасности» (16 часов), «Технология связанного азота, процессы и аппараты» (118 часов), «Контрольно-измерительные приборы» (30 часов), «Технология, процессы и аппараты производства» (72 часа), «Организация производства» (42 часа). Практическая часть включала в себя общее знакомство с комбинатом и работой цехов [6, с. 84]. Помимо вопросов, непосредственно связанных с химическим производством, болгарских специалистов обучали принципам «организации социалистического соревнования и стахановского движения», а также теории «планового регулирования зарплат» [3, с. 71 об.]. Помимо программы по подготовке инженеров была разработана программа двухмесячной подготовки для монтажников цеха серной кислоты [3, с. 82].

Учебный процесс был организован следующим образом. Bce прибывшие были разделены на 4 группы в зависимости от специализации, за каждой группой закреплялись цех и один из высококвалифицированных инженеров. По итогам обучения практиканты должны были сдать технические экзамены [3, с. 240-241]. За обучающимися руководством завода был закреплен руководитель, один из ведущих инженеров. На его содержание предусматривались отдельные расходы [3, с. 82].
Сведения о прохождении практики отражены в сохранившихся отчетах БАТЗ. Эти документы содержат в основном информацию о ходе учебного процесса. Очевидно, что процесс обучения не был гладким, в том числе и по вине его организаторов. На тот момент на заводе не было своей сформировавшейся профессионально-учебной базы, многие разделы учебной программы разрабатывались впервые, а инженеры, ответственные за практику, не успевали уделять ей должного внимания. В августе 1951 года со стороны практикантов была зафиксирована критика по поводу качества обучения. Руководитель производственной практики И. Финтушаль в своем отчете отмечал, что со стороны отдельных цеховых руководителей практики «отсутствует личный контроль за ходом производственного обучения болгарских специалистов и недостаточно проводятся консультации с ними», в связи с чем было рекомендовано усилить контроль и увеличить количество часов консультаций до окончания практики [3, с. 83].

Об уровне подготовки болгарских специалистов позволяют судить производственно-деловые характеристики ряда практикантов. В этих документах иногда встречаются отметки об отсутствии по итогам практики навыков, необходимых для работы, даются оценки организаторских способностей. О Стефане Лазарове, например, сказано, что «он не обладает организаторскими способностями и теоретическими знаниями, достаточными, чтоб работать в качестве мастера» [3, с. 298]. Сообщалось и о наличии проблемы языкового барьера. Так, про Пенчо Пенчева сказано, что «слабое знание русского языка в значительной мере затруднило товарищу Пенчеву практическое и теоретическое обучение», в связи с чем комиссия рекомендовала ему пройти дополнительную учебу [3, с. 304]. Но в целом, большинство практикантов получили положительные отзывы и рекомендации.

Были проблемы и с оформлением выпускных документов для практикантов, о чем директору БАТЗа А.Т. Семченко писал заместитель начальника управления внешний сношений МХП П. Афанасьев: 
«Обращаем ваше внимание на неправильное и небрежное составление присланных характеристик и аттестатов, ввиду чего последние не могут быть направлены иностранному Заказчику» [3, с. 110]. Афанасьев указывал, что аттестаты были заполнены от руки, с пропусками и исправлениями, а наименование граф в отдельных документах не совпадало с их содержанием. «Учитывая, что представленные вами документы направляются заграницу, просим на правильность и аккуратность их оформления обратить особое внимание», - писал П. Афанасьев [3, с. 110].

Этот непростой для всех участников опыт организации практики в итоге дал положительные результаты. Практиканты смогли получить необходимые для работы знания, применить их на родине. Димитровградский химический комбинат был пущен в эксплуатацию в 1952 году и стал одним из флагманов индустриальной экономики НРБ [4, с. 210]. Завод под именем акционерного общества «Неохим» и по сей день выпускает и импортирует азотные и фосфорные удобрения, перманганат калия [6].

В источниках сохранились и воспоминания самих практикантов об учебе. Большой интерес представляет переведенное на русский язык письмо руководителя группы Петра Статева руководству БАТЗ. В тексте он отметил, что полученная помощь в обучении является «беспрецедентной и очень полезной» для развития собственной промышленности в строящейся независимой Болгарии. «Сознавая высокую ответственность, которую возложили на нас народ и правительство, мы, группа практикантов, приложили все свои усилия и энтузиазм, овладение и полученные от советских друзей опыт, чтобы возвращаться в Болгарию смогли на деле приложить все полученное в стране строящегося коммунизма», - писал он в своем письме [3, с. 212].

Таким образом, сохранившиеся источники свидетельствуют, что Пермский край сыграл важную роль в становлении промышленности Болгарии в период ее пребывания в числе стран народной демократии. Специалисты флагманского для химической промышленности предприятия, Димитровградского химического комбината, проходили предпроизводственную практику и обучение в г. Березники. Несмотря на сложности с организацией учебного процесса, они получили необходимые для работы знания и компетенции, а пребывание в СССР оставило в их памяти положительные воспоминания. Данный исторический сюжет, помимо прочего, раскрывает и особенности обучения иностранцев на предприятиях СССР в 1950-е годы.

Пребывание болгар в Прикамье в 1950-е годы является еще одной важной страницей в истории болгар УралоСибирского региона.

\section{Библиографический список}

1. Всесоюзная перепись населения 1939 года. Национальный состав населения по регионам [Электронный ресурс]: Демоскоп weeky. URL: : http://www.demoscope.ru/weekly/ssp/rus_nac_39.php?reg=68 (дата обращения: 26.04.2020).

2. Всесоюзная перепись населения $195 \overline{9}$ года. Национальный состав населения по регионам России [Электронный ресурс]: Демоскоп weeky. http://www.demoscope.ru/weekly/ssp/rus_nac_59.php (дата обращения: 26.04.2020).

3. Государственный архив Пермского края (ГАПК). Ф. Р.-1656. Оп. 1. Д. 545. Материалы по индивидуальному обучению иностранных специалистов (Болгарских). 1950 г.

4. Димитровградский химический комбинат // Большая Советская Энциклопедия / под ред. А.М. Прохорова. 3-е изд. Т. 8. - М.: «Советская энциклопедия», 1972. - С. 267.

5. Договор о дружбе, сотрудничестве и взаимной помощи между СССР и НРБ // Ведомости Верховного Совета. - 1949. - № 6 (553). - С. 4.

6. За «Неохим» [Электронный ресурс]: Официальный сайт компании «Неохим» АД. URL.: $\quad$ https://web.archive.org/web/20100316143802/http://www.neochim.bg/main.php? module= content\&cnt_id=2 (дата обращения: 11.05.2020).

7. История Болгарии в двух томах. Т. 2. - М.: Изд-во АН СССР, 1955. - 610 с.

8. Каменских М.С. Китайцы Перми: история и культура. - СПб.: Маматов, 2018. - С. 20-28.

9. Михайлюк B.M. Не один пуд соли: Березники в судьбе России. -Пермь: Пушка, 1997. -368 с. 
10. Народы Пермского края: этническая история и современное этнокультурное развитие. Словарь-справочник. - СПб.: Маматов, 2014. - 416 с.

11. Пермский государственный архив социально-политической истории (ПермГАСПИ). Ф. 641/1. Оп. 1. Д. 7970. Добрев Иван Иванович.

12. Филипова М. П., Черных А. В., Каменских М. С. Болгары Перми: история и культура. - СПб.: Изд-во «Маматов», 2018. - 64 с.

\title{
SOVIET-BULGARIAN INTERACTION IN PERM REGION IN THE 1950s
}

\author{
M.S. Kamenskikh
}

\section{Perm Federal Research Center UB RAS}

In the article, major events related to the training of Bulgarian specialists at the Bereznikovsky nitrogen fertilizer plant in the 1950s have been reconstructed, based of previously unpublished archive materials of «AZOT» JSC fund of the State Archive of Perm Krai. The available sources make it possible to reconstruct the circumstances of Bulgarian specialists arrival, as well as their training course progress and content of the educational process. After the studies in Perm Region the Bulgarian specialists went back to their homeland providing personnel of the developing chemical industry. In particular, specialists trained in Berezniki were sent to Dimitrovgrad chemical integrated works, one of the leaders of Bulgarian industry in the 1950s. The research led us to conclusion that Perm Region made a significant contribution to the Bulgarian industrial development in the 1950s.

Keywords: the Bulgarian, Dimitrovgrad, Berezniki, USSR.

\section{Сведения об авторе}

Каменских Михаил Сергеевич, кандидат исторических наук, старший научный сотрудник отдела по исследованию политических институтов и процессов, Пермский федеральный исследовательский центр УрО РАН (ПФИЦ УрО РАН), 614990, г. Пермь, ул. Ленина, 13а; e-mail: pomidorrr@mail.ru 